\title{
Neuroprotective effects of phenylethanoid glycosides in an in vitro model of Alzheimer's disease
}

\author{
JIANHUA YANG ${ }^{1 *}$, BOWEI JU ${ }^{1,2^{*}}$, YAO YAN ${ }^{1}$, HUANHUAN XU ${ }^{1}$, \\ SHANSHAN WU ${ }^{1}$, DANDAN ZHU ${ }^{1}$, DANDAN CAO ${ }^{1}$ and JUNPING $\mathrm{HU}^{2}$ \\ ${ }^{1}$ Department of Pharmacy, The First Affiliated Hospital; ${ }^{2}$ Department of Natural Medicines, \\ College of Pharmacy, Xinjiang Medical University, Urumqi, Xinjiang 830011, P.R. China
}

Received January 8, 2016; Accepted January 6, 2017

DOI: $10.3892 /$ etm.2017.4254

\begin{abstract}
The present study aimed to investigate the neuroprotective effects of phenylethanol glycosides (PhGs) on $\mathrm{H}_{2} \mathrm{O}_{2}$ - and $\beta$-amyloid peptide $(\mathrm{A} \beta)_{1-42}$-induced injury of PC12 cells as an in vitro model of Alzheimer's disease (AD). The optimal induction conditions were established through screening of various incubation times and concentrations. PC12 cells were treated with $0.5 \mu \mathrm{M} \mathrm{A} \beta_{1-42}$ and $\mathrm{H}_{2} \mathrm{O}_{2}$ in the presence of PhGs for $24 \mathrm{~h}$ and the cell viability was then evaluated by an MTT assay; lactate dehydrogenase (LDH) release and malondialdehyde (MDA) content were also measured. The optimal conditions for establishing the AD model were the treatment of PC12 cells with $0.5 \mu \mathrm{M} \mathrm{A} \beta_{1-42}$ for $48 \mathrm{~h}$, or with $25 \mu \mathrm{M} \mathrm{H}_{2} \mathrm{O}_{2}$ dissolved in DMEM with PBS. PhGs at concentrations of 5,25 and $50 \mu \mathrm{g} / \mathrm{ml}$ increased the viability and decreased LDH and MDA release by PC12 cells injured with $\mathrm{A} \beta_{1-42}$ or $\mathrm{H}_{2} \mathrm{O}_{2}$. In conclusion, the model of $\mathrm{A} \beta_{1-42^{-}}$and $\mathrm{H}_{2} \mathrm{O}_{2}$-induced PC12 cell injury was successfully established. $\mathrm{PhGs}$ were shown to have a significant neuroprotective effect against $\mathrm{A} \beta_{1-42}$ - or $\mathrm{H}_{2} \mathrm{O}_{2}$-induced cell injury.
\end{abstract}

\section{Introduction}

Alzheimer's disease (AD), a neurodegenerative disorder with the clinical characteristics of progressive memory loss and cognitive function impairment (1), is the most common cause of dementia worldwide (2). The financial costs are immense due to the prevalence of AD (3). Hence, it is urgent to develop appropriate means for the management and prevention of $\mathrm{AD}$.

Correspondence to: Professor Junping Hu, Department of Natural Medicines, College of Pharmacy, Xinjiang Medical University, 393 Xinyi Road, Urumqi, Xinjiang 830011, P.R. China

E-mail: hjp-yft@163.com

${ }^{*}$ Contributed equally

Key words: phenylethanol glycosides, $\mathrm{PC} 12$ cells, $\mathrm{H}_{2} \mathrm{O}_{2}$, $\beta$-amyloid peptide $_{1-42}$, neuroprotection
The pathogenesis of AD is closely associated with the accumulation of neurofibrillary tangles and senile plaques (SPs) in affected brain regions $(4,5)$. $\beta$-amyloid peptide $(A \beta)$, the major component of SPs, has been reported to have a causative role in the progression of $\mathrm{AD}$ as has a toxic effect on neuronal cells (6). $A \beta$ fragments, including $A \beta_{1-40}, A \beta_{25-35}$ and $A \beta_{1-42}$, have been generated through the split of amyloid precursor protein (7). The neurotoxicity of $A \beta_{1-42}$ was found to be significantly higher than that of $A \beta_{25-35}$ and $A \beta_{1-40}$, and $\mathrm{A} \beta_{1-42}$ is able to induce an AD model (1,8-10). Oxidative stress may be involved in the pathogenesis of $\mathrm{AD}$ and is the major mechanism underlying $A \beta$-induced neurotoxicity (11-13). Several studies suggested that $A \beta_{1-42}$ caused intracellular accumulation of reactive oxygen species (ROS), leading to lipid and protein oxidation, DNA damage and activation of cell cycle checkpoint signaling $(1,14,15)$. Excessive amounts of $\mathrm{H}_{2} \mathrm{O}_{2}$ may lead to oxidative damage and induce apoptosis of PC12 cells (16). Therefore, targeting of oxidative stress may be a promising approach for the development of therapeutic strategies for inhibiting $\mathrm{A} \beta$-induced neurotoxicity in AD.

Herba (H.) Cistanche, a Chinese herbal medicine commonly used in mainland China for nourishing the kidneys and replenishing essence and blood, has been used to treat memory loss and senile constipation (17). Phenylethanoid glycoside (PhG), one of the major constituents in H. Cistanche, improves the impairment of neuronal apoptosis caused by $\mathrm{A} \beta_{25-35}$ via its anti-oxidant effects $(18,19)$. A previous study identified five major components from total $\mathrm{PhGs}$, namely acteoside, 2'-acetylacteoside, echinacoside, cistanosides and isoacteoside (20). Among these components, acteoside and echinacoside have been reported to have neuroprotective effects on $\mathrm{A} \beta_{25-35^{-}}$or $\mathrm{H}_{2} \mathrm{O}_{2}$-induced neurotoxicity (21-23). For instance, Wu et al (24) suggested that acteoside and echinacoside ameliorated cognitive dysfunction caused by $\mathrm{A} \beta_{1-42}$. The present study aimed to investigate the protective effects of PhGs in an in vitro rat cell model of AD.

\section{Materials and methods}

Preparation of PhGs. Total PhGs were extracted from $H$. Cistanche as previously described (25). The air-dried stem of $H$. Cistanche was powdered and extracted by percolation with $80 \% \mathrm{EtOH}$. The percolate was evaporated under reduced 
pressure, followed by re-suspension in an appropriate amount of $\mathrm{H}_{2} \mathrm{O}_{2}(100 \mu \mathrm{mol} / \mathrm{l})$. The mixture was isolated on an SP-825 macroporous resin column (Mitsubishi Chemical, Tokyo, Japan) and eluted with 0, 30, 50, 70 and $90 \% \mathrm{EtOH}$ in water. To obtain the PhG-rich fraction, the 30-50\% EtOH eluents were concentrated and dried under reduced pressure. Ultraviolet (UV) spectrophotometry was performed to determine the total PhGs. The content of echinacoside and acteoside was determined by high-pressure liquid chromatography according to a previous protocol (26). A Hypersil ODS-2 column (4.6x250 mm, $5 \mu \mathrm{m}$; Dalian Elite Analytical Instruments, Co., Ltd., Dalian, China) was used and maintained at room temperature. The mobile phases were methyl cyanides and water containing $0.4 \%$ phosphoric acid (v/v; Sigma-Aldrich; Merck $\mathrm{KGaA}$, Darmstadt, Germany). The flow rate was $0.75 \mathrm{ml} / \mathrm{min}$ and the wavelength was set to $333 \mathrm{~nm}$.

Cell culture and drug treatment. The PC12 rat pheochromocytoma cell line was provided by Dr He Chunhui, the Medical School, Xinjiang Medical University (Urumqi, China). Cells were cultured in high-glucose Dulbecco's modified Eagle's medium (DMEM; Thermo Fisher Scientific, Inc., Waltham, MA, USA) containing 10\% fetal bovine serum (Sangon Biotech Co. Ltd., Shanghai, China), $100 \mathrm{U} / \mathrm{ml}$ penicillin and $100 \mathrm{U} / \mathrm{ml}$ streptomycin in an incubator at $37^{\circ} \mathrm{C}$ containing $5 \%$ $\mathrm{CO}_{2}$ and $95 \%$ air. Upon reaching $80 \%$ confluence, the cells were treated with $0.25 \%$ trypsin and passaged.

In order to eliminate the interference of the drug itself on the growth of PC12 cells, a toxicity experiment was performed. In brief, PC12 cells $\left(3 \times 10^{4}\right.$ cells $\left./ \mathrm{ml}\right)$ were seeded in 96-well plates at $100 \mu \mathrm{l} /$ well and incubated at $37^{\circ} \mathrm{C}$ overnight. After discarding the supernatant, $200 \mu 1$ complete DMEM was added in the blank group, while cells in the intervention groups were treated by PhGs at various doses $(5,25,50,75,100,125$, $150,175$ and $200 \mu \mathrm{g} / \mathrm{ml})$. Following incubation of the cells at $37^{\circ} \mathrm{C}$ for $48 \mathrm{~h}, 20 \mu \mathrm{l} \mathrm{MTT}$ solution (Sigma-Aldrich; Merck $\mathrm{KGaA}$ ) was added to each well. After incubation for $4 \mathrm{~h}$, the supernatant was discarded and $150 \mu \mathrm{l}$ dimethylsulfoxide was added per well, followed by agitation for $10 \mathrm{~min}$. The optical density (OD) values at $490 \mathrm{~nm}$ were detected using an ELISA plate reader.

A $\beta_{1-42}$-induced PC12 cell injury. A $\beta_{1-42}$ peptide purchased from Bioss Biotech (Beijing, China) was dissolved in water (100 $\mu \mathrm{g} / \mathrm{ml})$. Subsequently, the mixture was incubated at $37^{\circ} \mathrm{C}$ for 4 days and stored at $4^{\circ} \mathrm{C}$ prior to use.

PC12 cells were seeded in 96-well plates $\left(3 \times 10^{4}\right.$ cells in $100 \mu \mathrm{l}$ per well). After culture for $24 \mathrm{~h}$ for adherence, $50 \mu \mathrm{l}$ $\mathrm{A} \beta_{1-42}$ at various final concentrations $(0,0.25,0.5,1,1.5$ or $2 \mu \mathrm{M}$ ) dissolved in serum-free DMEM was added, followed by incubation for 24, 48, 72 or $96 \mathrm{~h}$. Cell viability was evaluated by an MTT assay. The optimal $\mathrm{A} \beta_{1-42}$ concentration was 0.5 determined to be $\mu \mathrm{M}$.

PC12 cells $\left(3 \times 10^{4}\right.$ cells per well) were treated with various doses of $\mathrm{PhGs}(0,0.5,5,25$ or $50 \mu \mathrm{g} / \mathrm{ml})$ in the presence of $0.5 \mu \mathrm{M} \mathrm{A} \beta_{1-42}$ for $24 \mathrm{~h}$. Cell viability was evaluated by an MTT assay.

$\mathrm{H}_{2} \mathrm{O}_{2}$-induced $\mathrm{PC} 12$ cell injury. $\mathrm{PC} 12$ cells were plated seeded in 96 -well plates $\left(3 \times 10^{4}\right.$ cells in $100 \mu \mathrm{l}$ per well). After culture for $24 \mathrm{~h}$ for adherence, $100 \mu \mathrm{l} \mathrm{H}_{2} \mathrm{O}_{2}$ at various final concentrations $(0,25,50,100,200,300,400$ and $500 \mu \mathrm{M})$ dissolved in DMEM with or without PBS (0.01 mol/l) was added, followed by incubation for $24 \mathrm{~h}$. Cell viability was evaluated by an MTT assay. The optimal $\mathrm{H}_{2} \mathrm{O}_{2}$ concentration and solvent was determined to establish the in vitro model of $\mathrm{AD}$.

PC12 cells $\left(3 \times 10^{4}\right.$ cells per well) were treated with various doses of PhGs $(0,0.5,5,25$ and $50 \mu \mathrm{M})$. After culture for $24 \mathrm{~h}$ for adherence, PC12 cells were treated with $100 \mu \mathrm{l} \mathrm{H}_{2} \mathrm{O}_{2}$ dissolved in DMEM with PBS in the presence of PhGs for $24 \mathrm{~h}$. The cell viability was evaluated by an MTT assay.

Lactate dehydrogenase $(L D H)$ release assay. Cell injury was assessed through measuring the LDH activity in the supernatant of PC12 cells using an LDH kit according to the manufacturer's protocol (cat. no. 20150604; Nanjing Jiancheng Bioengineering Institute, Nanjing, China). In brief, double-distilled $\mathrm{H}_{2} \mathrm{O}, 0.2 \mu \mathrm{mol} / \mathrm{ml}$ pyruvic acid, matrix buffer and coenzyme I buffer were added in sequence at $48 \mathrm{~h}$ after drug treatment. After incubation at $37^{\circ} \mathrm{C}$ for $15 \mathrm{~min}$, 2,4-dinitro-phenylhydrazine was added. Subsequently, $250 \mu \mathrm{l}$ of a $0.4 \mathrm{M} \mathrm{NaOH}$ solution was added to each well. The supernatant was collected after incubation for $30 \mathrm{~min}$ at room temperature. The absorbance at $450 \mathrm{~nm}$ was then measured with a microplate reader.

Measurement of malondialdehyde (MDA). MDA was measured in the supernatant of PC12 cells using commercial kit (cat. no. 20150604; Nanjing Jiancheng Bioengineering Institute) according to the manufacturer's protocol In brief, dehydrated alcohol and other reagents were added in order, followed by incubation in a water bath at $95^{\circ} \mathrm{C}$ for $40 \mathrm{~min}$. The mixture was centrifuged at $1,006 \mathrm{x} g$ and $25^{\circ} \mathrm{C}$ for $10 \mathrm{~min}$ after cooling. The supernatant was then used to determine the MDA content. Absorbance was subsequently measured with a microplate reader at $532 \mathrm{~nm}$.

Assessment of protective effects of echinacoside and acteoside against $A D$ in vitro. $\mathrm{PC} 12$ cells were seeded at a density of $3 \times 10^{4}$ cells/well in 96-well plates (100 $\mu \mathrm{l} /$ well). Cells were incubated with drugs including echinacoside (cat. no. 111670-200503; National Institutes for Food and Drug Control, Beijing, China) and acteoside (cat. no. 111530-200505; National Institutes for Food and Drug Control) at various concentrations $(0.5,25$ and $50 \mu \mathrm{g} / \mathrm{ml})$. Subsequently, the cells were treated with $\mathrm{A} \beta_{1-42}$ or $\mathrm{H}_{2} \mathrm{O}_{2}$ for $24 \mathrm{~h}$ and the cell viability was measured by an MTT assay.

Statistical analysis. Values are expressed as the mean \pm standard deviation. Student's t-test was used for inter-group comparisons. Statistical analyses were performed using SPSS 18.0 (SPSS, Inc., Chicago, IL, USA). $\mathrm{P}<0.05$ was considered to indicate a statistically significant difference.

\section{Results}

Quantification of PhGs from H. Cistanches. The UV spectra of the PhGs extracted as well as standard solutions of echinacoside and acteoside were recorded, and the results showed that the UV spectra were consistent (Fig. 1). UV spectrophotometry 


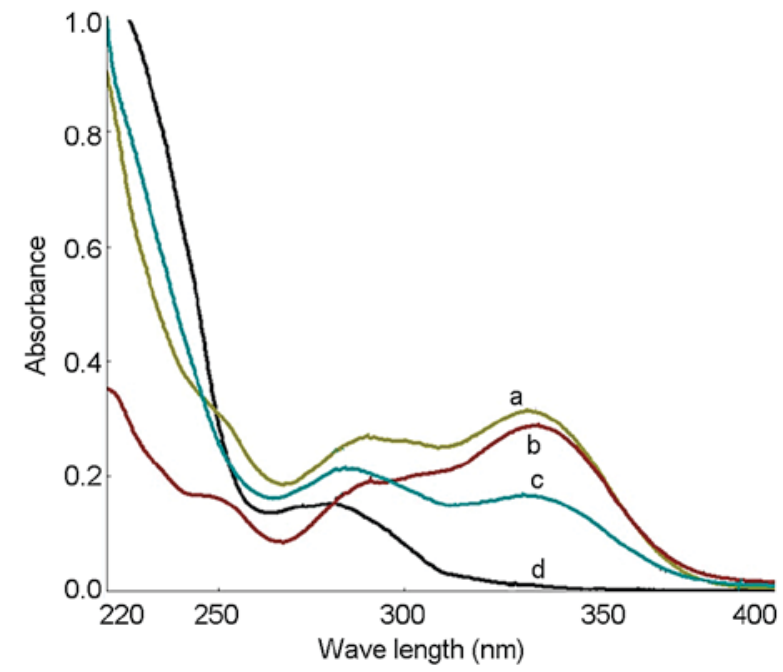

Figure 1. Ultraviolet spectrum of (a) echinacoside, (b) acteoside (c) phenylethanoid glycosides extracted in the present study, and (d) blank control.

showed that the $\mathrm{PhG}$ content was $87.6 \%$. The HPLC results showed that the contents of echinacoside and acteoside were 37.7 and $17.8 \%$, respectively (Fig. 2).

Determination of the ideal PhG concentration. Compared with the blank group, PhG at 75, 100, 125, 150, 175 and $200 \mu \mathrm{g} / \mathrm{ml}$ had a significant inhibitory effect on PC12 cells $(\mathrm{P}<0.05)$, while $\mathrm{PhG}$ at 5, 25 and $50 \mu \mathrm{g} / \mathrm{ml}$ showed low toxicity on PC12 cells, and the cell viability was $>80 \%$ (Fig. 3). Thus, $\mathrm{PhGs}$ at the concentration of 5, 25 and $50 \mu \mathrm{g} / \mathrm{ml}$ was used for treating PC12 cells in subsequent experiments due to not affecting the cell viability.

A $\beta_{1-42}$-induced PC12 cell injury. Compared with that in the control group, the cell viability in the $0.5 \mu \mathrm{M} \mathrm{A} \beta_{1-42}$ injury group was $63 \%(\mathrm{P}<0.05)$. The cell viability was decreased by $\mathrm{A} \beta_{1-42}$ in a concentration-dependent manner, and the viability was $<50 \%$ in the $1,1.5$ and $2 \mu \mathrm{M} \mathrm{A} \beta_{1-42}$ injury groups (Fig. 4). Thus, treatment with $0.5 \mu \mathrm{M} \mathrm{A} \beta_{1-42}$ for $48 \mathrm{~h}$ was determined to be the optimal condition for establishing the in vitro $\mathrm{AD}$ model.

The activity of PC12 cells treated with $0.5 \mu \mathrm{M} \mathrm{A} \beta_{1-42}$ in the presence of safe doses of PhGs $(5,25$ and $50 \mu \mathrm{g} / \mathrm{ml})$ for $24 \mathrm{~h}$ was also determined. Compared with the model group $(\mathrm{P}<0.01), \mathrm{PhG}$ showed a significant neuroprotective effect on PC12 cells. The cell viability was rescued by $\mathrm{PhGs}$ in a dose-dependent manner (Fig. 5).

$\mathrm{H}_{2} \mathrm{O}_{2}$-induced PC12 cell injury. The viability of PC12 cells treated with $25 \mu \mathrm{M} \mathrm{H}_{2} \mathrm{O}_{2}$ dissolved in DMEM with PBS was $56.43 \%$. The viability of PC12 cells treated with $200 \mu \mathrm{M} \mathrm{H}_{2} \mathrm{O}_{2}$ dissolved in DMEM without PBS was $71.64 \%$ (Table I). Thus, PC12 cells treated with $25 \mu \mathrm{M} \mathrm{H}_{2} \mathrm{O}_{2}$ dissolved in DMEM with PBS was the selected as the optimal condition for establishing the AD model.

Compared with the control group, the cell viability in the model group was $48.8 \%(\mathrm{P}<0.05)$. Compared with the model group, $\mathrm{PhGs}$ had a significant neuroprotective effect on $\mathrm{PC} 12$ cells. The cell viability was dose-dependently increased by

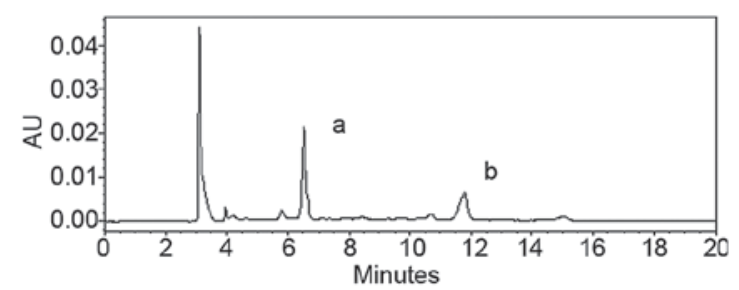

Figure 2. High-performance liquid chromatography spectrum showing (a) echinacoside and (b) acteoside.

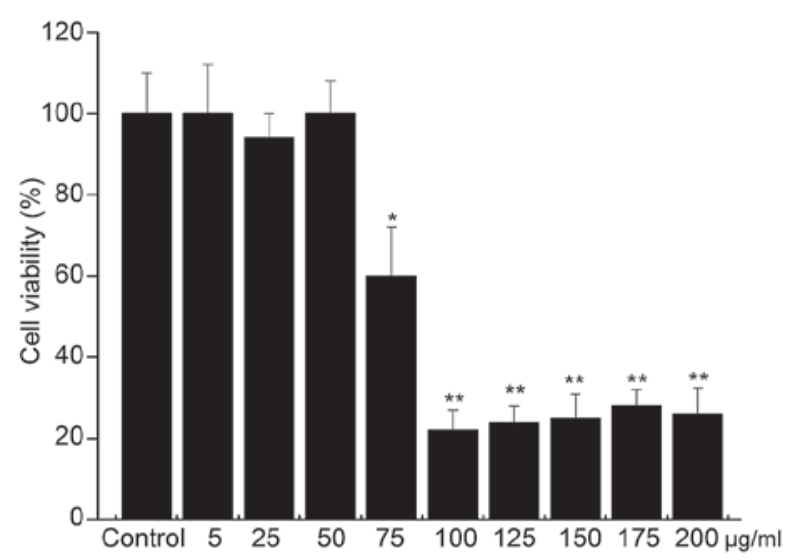

Figure 3. Dose screening of phenylethanoid glycosides to determine an optimal concentration to not affect cell viability. ${ }^{*} \mathrm{P}<0.05$, vs. control; ${ }^{* * *} \mathrm{P}<0.05$, vs. control.

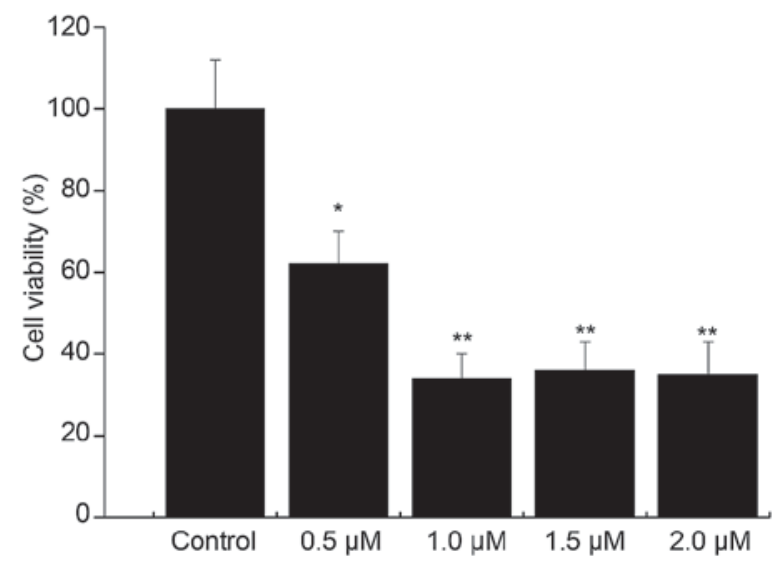

Figure 4. Screening of â-amyloid peptide ${ }_{1-42}$ damage conditions. ${ }^{*} \mathrm{P}<0.05$, vs. control; ${ }^{* *} \mathrm{P}<0.05$, vs. control.

PhGs, and the viability of PC12 cells treated with PhGs at concentrations of 5,25 and $50 \mu \mathrm{g} / \mathrm{ml}$ was 54,57 and $64 \%$, respectively (Table II).

PhGs inhibit injury-induced LDH release by PC12 cells. Compared with the control group, the LDH content of the supernatant of injured PC12 cells was increased, which was inhibited by PhGs in a concentration-dependent manner. This result indicated that $\mathrm{PhGs}$ have a significant neuroprotective effect on PC12 cells (Fig. 6). 
Table I. Cell viability (\%) after $\mathrm{H}_{2} \mathrm{O}_{2}$ treatment.

\begin{tabular}{lcc}
\hline & \multicolumn{2}{c}{ Solvent } \\
\cline { 2 - 3 }$(\mu \mathrm{M})$ & DMEM+PBS & DMEM \\
\cline { 2 - 3 } & 100 & 100 \\
0 & $56.43^{\mathrm{a}}$ & 107.61 \\
25 & $54.81^{\mathrm{a}}$ & 108.13 \\
50 & $52.79^{\mathrm{a}}$ & 105.01 \\
100 & $46.30^{\mathrm{a}}$ & $71.64^{\mathrm{a}}$ \\
200 & $53.90^{\mathrm{a}}$ & $60.06^{\mathrm{a}}$ \\
300 & $44.28^{\mathrm{a}}$ & $61.00^{\mathrm{a}}$ \\
400 & 43.68 & $60.17^{\mathrm{a}}$ \\
500 & & \\
\hline
\end{tabular}

${ }^{\text {aa }}<0.05$ vs. control group. PhGs, phenylethanoid glycosides; DMEM, Dulbecco's modified Eagle's medium; PBS, phosphate-buffered saline.

Table II. Cell viability after drug interference.

\begin{tabular}{lc}
\hline Group & Cell viability $(\%)$ \\
\hline Control & 100 \\
Model & $48.83^{\mathrm{a}}$ \\
PhG $5 \mu \mathrm{g} / \mathrm{ml}$ & $53.94^{\mathrm{b}}$ \\
PhG $25 \mu \mathrm{g} / \mathrm{ml}$ & $57.39^{\mathrm{b}}$ \\
PhG $50 \mu \mathrm{g} / \mathrm{ml}$ & $64.00^{\mathrm{c}}$ \\
\hline
\end{tabular}

${ }^{\mathrm{a}} \mathrm{P}<0.05$, vs. control group; ${ }^{\mathrm{b}} \mathrm{P}<0.05$, vs. model group; ${ }^{\mathrm{c}} \mathrm{P}<0.05$, vs. model group. PhGs, phenylethanoid glycosides.

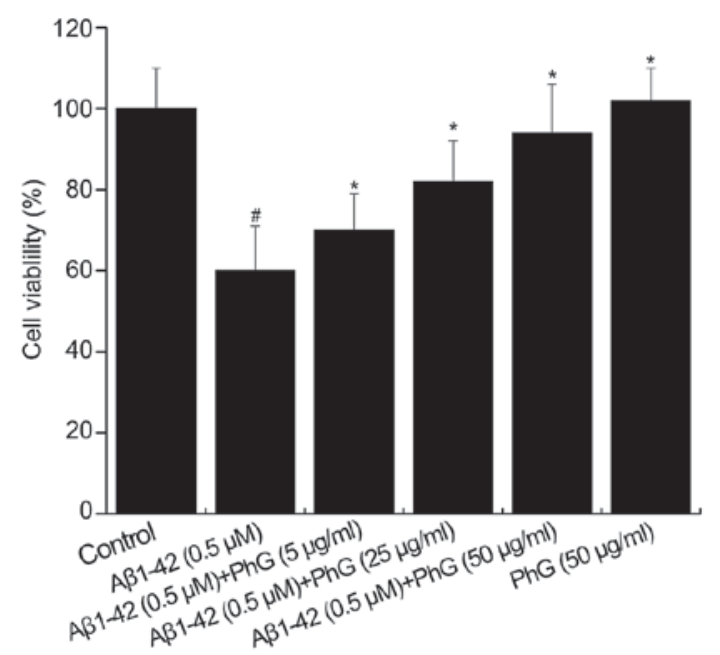

Figure 5. Cell viability of PC12 cells treated with $\mathrm{A} \beta_{1-42}$ and PhGs. ${ }^{*} \mathrm{P}<0.05$, vs. control group; "P<0.05, vs. model group. $\mathrm{A} \beta$, â-amyloid peptide; PhGs, phenylethanoid glycosides.

PhGs inhibit injury-induced MDA production by PC12 cells. Compared with the control group, the MDA content in the supernatant of injured PC12 cells was increased, which was
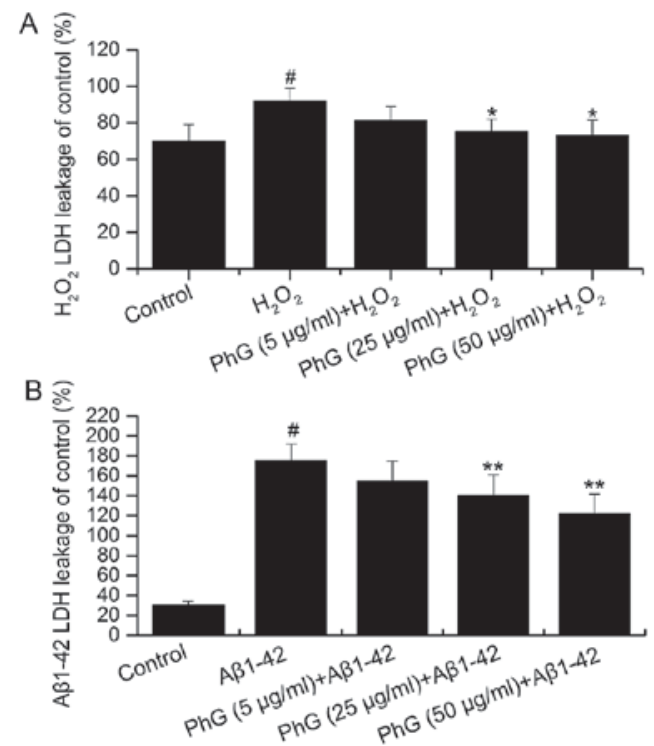

Figure 6. $\mathrm{LDH}$ release after (A) $\mathrm{H}_{2} \mathrm{O}_{2}$ interference and (B) $\mathrm{A} \beta_{1-42}$ interference in an in vitro model of Alzheimer's disease. " $\mathrm{P}<0.05$, vs. control group; ${ }^{*} \mathrm{P}<0.05$, vs. model group; ${ }^{* *} \mathrm{P}<0.05$, vs. model group. $\mathrm{LDH}$, lactate dehydrogenase; $\mathrm{A} \beta$, â-amyloid peptide; PhGs, phenylethanoid glycosides.
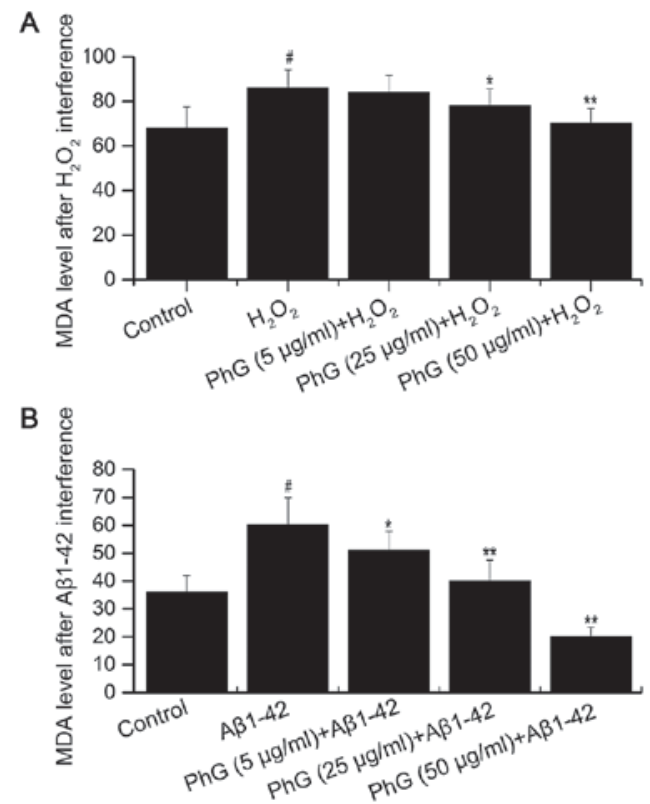

Figure 7. Determination of MDA after (A) $\mathrm{H}_{2} \mathrm{O}_{2}$ interference and (B) $\mathrm{A} \beta_{1-42}$ interference in an in vitro model of Alzheimer's disease. ${ }^{\prime \prime} \mathrm{P}<0.05$, vs. control group; ${ }^{*} \mathrm{P}<0.05$, vs. model group; ${ }^{* *} \mathrm{P}<0.05$, vs. model group. MDA, malondialdehyde; A $\beta$, â-amyloid peptide; PhGs, phenylethanoid glycosides.

inhibited by PhGs in a concentration-dependent manner. This result indicated that $\mathrm{PhGs}$ have a significant neuroprotective effect on PC12 cells (Fig. 7).

PhG and its components echinacoside and acteoside rescue the viability of injured PC12 cells. Compared with the model group, treatment with acteoside significantly increased the viability of $\mathrm{A} \beta_{1-42}$-injured PC12 cells in a dose dependent manner. PhGs and echinacoside also significantly increased the viability of $\mathrm{A} \beta_{1-42}$-injured PC12 cells at all concentrations tested (Fig. 8A). 

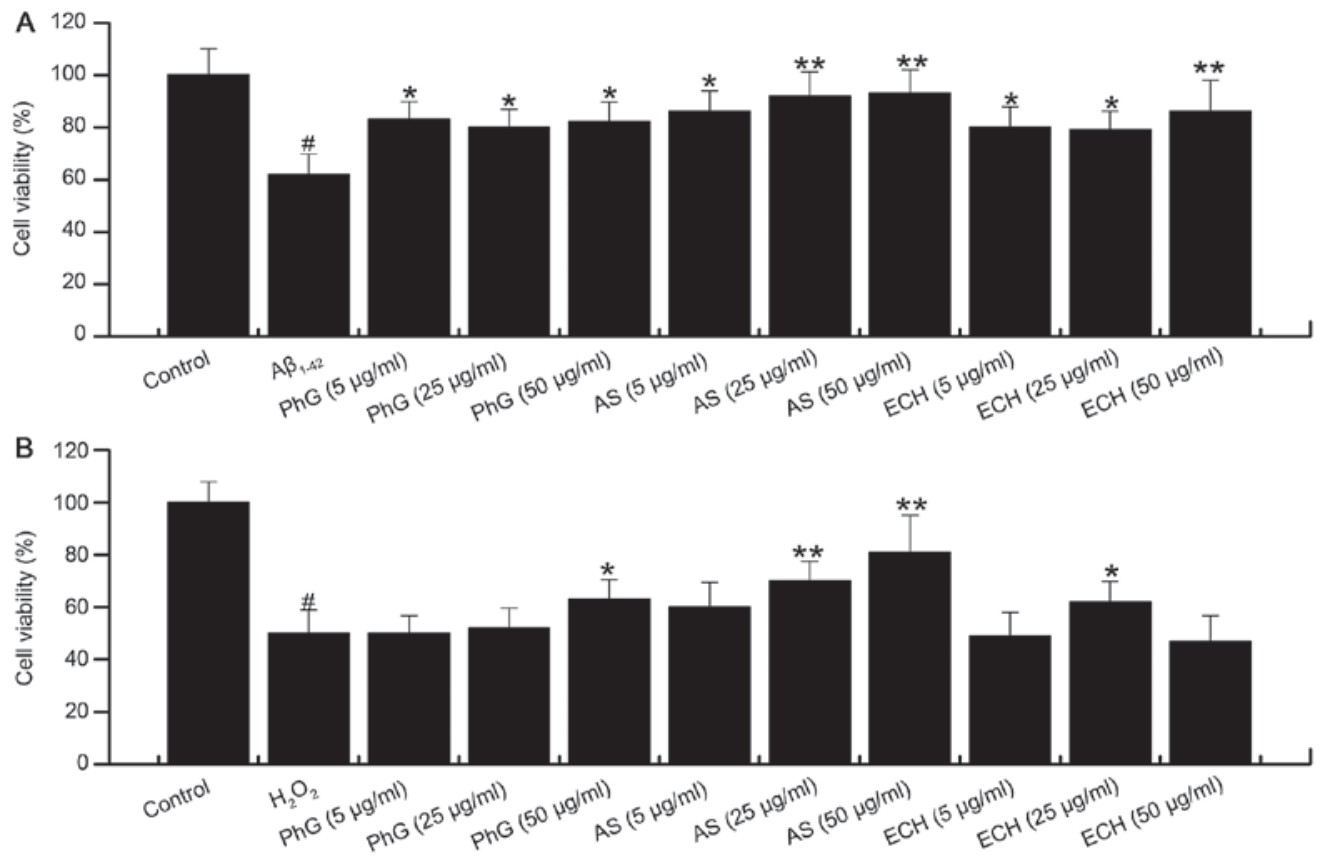

Figure 8. Protective effects of PhGs, ECH and AS on the cells treated with (A) $\mathrm{A} \beta_{1-42}$ and $(\mathrm{B}) \mathrm{H}_{2} \mathrm{O}_{2} .{ }^{~} \mathrm{P}<0.05$, vs. control group; ${ }^{*} \mathrm{P}<0.05$, vs. model group; ${ }^{* *} \mathrm{P}<0.05$, vs. model group. $\mathrm{A} \beta$, â-amyloid peptide; PhGs, phenylethanoid glycosides; ECH, echinacoside; AS, acteoside.

Compared with the model group, acteoside significantly increased the viability of $\mathrm{PC} 12$ cells treated with $\mathrm{H}_{2} \mathrm{O}_{2}$. PhGs also increased the viability of $\mathrm{PC} 12$ cells treated with $\mathrm{H}_{2} \mathrm{O}_{2}$, while the effect was not significant at concentrations of 5 and $25 \mu \mathrm{g} / \mathrm{ml}$ (Fig. 8B). In addition, echinacoside increased the cell viability at $25 \mu \mathrm{g} / \mathrm{ml}$.

In conclusion, acteoside, $\mathrm{PhGs}$ and echinacoside exerted significant neuroprotective effects on PC12 cells subjected to injury with $\mathrm{A} \beta_{1-42}$ or $\mathrm{H}_{2} \mathrm{O}_{2}$.

\section{Discussion}

Oxidative stress is the major mechanism underlying A $\beta$-mediated neurotoxicity in AD (11-13). Therefore, targeting oxidative stress may represent an approach for the treatment of $\mathrm{AD}$. In the present study, an in vitro model of $\mathrm{AD}$ comprising $\mathrm{A} \beta_{1-42}$ - and $\mathrm{H}_{2} \mathrm{O}_{2}$-induced $\mathrm{PC} 12$ cell injury was successfully established. Results of the MTT, LDH and MDA assays showed that PhGs increased the cell viability, and decreased LDH and MDA release by PC12 cells subjected to injury. It can be concluded that $\mathrm{PhGs}$ have significant neuroprotective effects on PC12 cells.

In order to reduce the effects of PhGs themselves on PC12 cell growth and prevent abnormal proliferation, the safe dose of PhGs was determined in a screening assay. The results showed that PhGs at 75, 100, 125, 150, 175 and $200 \mu \mathrm{g} / \mathrm{ml}$ had a significant inhibitory effect on $\mathrm{PC} 12$ cells $(\mathrm{P}<0.05, \mathrm{P}<0.01)$, while cell viability remained $>80 \%$ at concentrations of 5,25 and $50 \mu \mathrm{g} / \mathrm{ml}$. Thus, PhGs at the concentration of 5, 25 and $50 \mu \mathrm{g} / \mathrm{ml}$ were safe for PC12 cells.

The injury by $A \beta_{1-42}$ was affected by certain factors, including the solvent, incubation time and product quality. In the present study, $\mathrm{A} \beta_{1-42}$ peptide was dissolved in water $(100 \mu \mathrm{g} / \mathrm{ml})$ and incubated at $37^{\circ} \mathrm{C}$ for 4 days in a $\mathrm{CO}_{2}$ incubator prior to use. PC12 cells were treated with $\mathrm{A} \beta_{1-42}$ at concentrations of $0.5,1,1.5$ and $2 \mu \mathrm{M}$. The results showed that the cell viability was decreased with the increase of $A \beta_{1-42}$, and the viability was $<50 \%$ in the $1,1.5$ and $2 \mu \mathrm{M} \mathrm{A} \beta_{1-42}$ injury groups. Thus, treatment of $\mathrm{PC} 12$ cells with $0.5 \mu \mathrm{M}$ $\mathrm{A} \beta_{1-42}$ for $48 \mathrm{~h}$ was determined to be the optimal condition for establishing the AD model. $A \beta_{25-35}$ has been commonly used to establish AD models due to low cost and simple operation (27-29). The neurotoxicity of $A \beta_{1-42}$ is significantly higher than that of $A \beta_{25-35}$, and $A \beta_{1-42}$ is therefore the optimal $A \beta$ fragment for establishing an AD model (1,8-10).

$\mathrm{H}_{2} \mathrm{O}_{2}$ is an oxidizer and excessive $\mathrm{H}_{2} \mathrm{O}_{2}$ may cause oxidative damage and induce cell apoptosis (30). In the present study, PC12 cells were treated with 25-500 $\mu \mathrm{M} \mathrm{H}_{2} \mathrm{O}_{2}$ dissolved in DMEM with or without PBS. The results showed that $\mathrm{H}_{2} \mathrm{O}_{2}$ dissolved in DMEM without PBS caused abnormal proliferation of PC12 cells. Thus, treatment of PC12 cells with $25 \mu \mathrm{M}$ $\mathrm{H}_{2} \mathrm{O}_{2}$ dissolved in DMEM with PBS was the optimal condition for establishing the AD model. $\mathrm{A} \beta_{1-42}$-induced injury was greater than $\mathrm{H}_{2} \mathrm{O}_{2}$-induced injury due to poor stability of $\mathrm{H}_{2} \mathrm{O}_{2}$ and solvent effects.

When the cell is damaged, $\mathrm{LDH}$ leakage into the culture medium is significantly increased. ROS is known to cause the production of MDA. The content of MDA and LDH therefore reflect the amount of oxidative damage. In the present study, damage-induced LDH and MDA activity was decreased with increasing doses of PhGs. These results indicated that $\mathrm{PhGs}$ have a significant neuroprotective effect on PC12 cells. The MTT assay showed that PhGs exhibited a dose-dependent neuroprotective effect on PC12 cells.

In conclusion, an in vitro model of $\mathrm{AD}$ comprising $\mathrm{A} \beta_{1-42^{-}}$and $\mathrm{H}_{2} \mathrm{O}_{2}$-induced PC12 cell injury was successfully established. Treatment with $\mathrm{PhGs}$ increased the cell viability, and decreased LDH and MDA release by PC12 cells treated with $\mathrm{A} \beta_{1-42}$ or $\mathrm{H}_{2} \mathrm{O}_{2}$. PhGs had a significant neuroprotective effect on $\mathrm{A} \beta_{1-42}$ - or $\mathrm{H}_{2} \mathrm{O}_{2}$-induced cell injury. 


\section{References}

1. Qu M, Zhou Z, Xu S, Chen C, Yu Z and Wang D: Mortalin overexpression attenuates beta-amyloid-induced neurotoxicity in SH-SY5Y cells. Brain Res 1368: 336-345, 2011.

2. Uzun S, Kozumplik O and Folnegović-Smalc V: Alzheimer's dementia: current data review. Collegium antropologicum 35: 1333-1337, 2011.

3. Brookmeyer R, Johnson E, Ziegler-Graham K and Arrighi HM: Forecasting the global burden of Alzheimer's disease. Alzheimer's \& dementia 3: 186-191, 2007.

4. Castellani RJ, Rolston RK and Smith MA: Alzheimer disease. Disease-a-month 56: 484-546, 2010.

5. Mattson MP: Pathways towards and away from Alzheimer's disease. Nature 430: 631-639, 2004.

6. Gouras GK, Tsai J, Naslund J, et al: Intraneuronal A $\beta 42$ accumulation in human brain. The American journal of pathology 156: $15-20,2000$

7. Shen $\mathrm{C}$, Chen Y, Liu $\mathrm{H}$, et al: Hydrogen peroxide promotes $\mathrm{A} \beta$ production through JNK-dependent activation of $\gamma$-secretase. Journal of Biological Chemistry 283: 17721-17730, 2008

8. Shih P-H and Wu C-H, Yeh C-T and Yen G-C: Protective effects of anthocyanins against amyloid $\beta$-peptide-induced damage in neuro-2A cells. Journal of agricultural and food chemistry 59 1683-1689, 2011.

9. Figueiredo CP, Bicca MA, Latini A, Prediger R, Medeiros R and Calixto JB: Folic acid plus $\alpha$-tocopherol mitigates amyloid- $\beta$-induced neurotoxicity through modulation of mitochondrial complexes activity. Journal of Alzheimer's disease: JAD 24: 61-75, 2010.

10. Dumont M, Lin MT and Beal MF: Mitochondria and antioxidant targeted therapeutic strategies for Alzheimer's disease. Journal of Alzheimer's disease: JAD 20: S633, 2010.

11. Sonnen JA, Breitner JC, Lovell MA, Markesbery WR, Quinn JF and Montine TJ: Free radical-mediated damage to brain in Alzheimer's disease and its transgenic mouse models. Free Radical Biology and Medicine 45: 219-230, 2008.

12. Lin MT and Beal MF: Mitochondrial dysfunction and oxidative stress in neurodegenerative diseases. Nature 443: 787-795, 2006.

13. Trushina $\mathrm{E}$ and McMurray C: Oxidative stress and mitochondrial dysfunction in neurodegenerative diseases. Neuroscience 145 : 1233-1248, 2007.

14. Huang S-H, Lin C-M and Chiang B-H: Protective effects of Angelica sinensis extract on amyloid $\beta$-peptide-induced neurotoxicity. Phytomedicine 15: 710-721, 2008.

15. Burhans WC and Heintz NH: The cell cycle is a redox cycle: linking phase-specific targets to cell fate. Free Radical Biology and Medicine 47: 1282-1293, 2009.

16. Xue HY, Gao GZ, Lin QY, Jin LJ and Xu YP: Protective effects of aucubin on $\mathrm{H}_{2} \mathrm{O}_{2}$-induced apoptosis in $\mathrm{PC} 12$ cells. Phytotherapy Research 26: 369-374, 2012.

17. Li X, Gou C, Yang H, Qiu J, Gu T and Wen T: Echinacoside ameliorates D-galactosamine plus lipopolysaccharide-induced acute liver injury in mice via inhibition of apoptosis and inflammation. Scandinavian journal of gastroenterology 49: 993-1000, 2014.
18. Liu, F-x Wang, X-w Luo L and Xin H, Na B and Wang X-f: The effects of glycosides of cistanche on learning and memory in beta-amyloid peptide induced Alzheimers disease in mice and its possible mechanism. Chinese Pharmacological Bulletin 22: $595,2006$.

19. Bao B, Tang X, Tian H, Tong $\mathrm{Y}, \mathrm{Wu} \mathrm{W}$ and Hong $\mathrm{Y}$ : Antioxidant activity of extracts from desert living Cistanche tubulosa (Schrenk) R. Wright Shanghai J Tradit Chin Med 44: 68-71, 2010

20. Jiang Y, Li S, Wang Y, Chen X and Tu P: Differentiation of Herba Cistanches by fingerprint with high-performance liquid chromatography-diode array detection-mass spectrometry. Journal of Chromatography A 1216: 2156-2162, 2009.

21. Wang $\mathrm{H}, \mathrm{Xu} \mathrm{Y,} \mathrm{Yan} \mathrm{J,} \mathrm{et} \mathrm{al:} \mathrm{Acteoside} \mathrm{protects} \mathrm{human} \mathrm{neuro-}$ blastoma SH-SY5Y cells against $\beta$-amyloid-induced cell injury. Brain research 1283: 139-147, 2009.

22. Zhao Q, Gao J, Li W and Cai D: Neurotrophic and neurorescue effects of Echinacoside in the subacute MPTP mouse model of Parkinson's disease. Brain research 1346: 224-236, 2010.

23. Kuang R, Sun Y, Yuan W, Lei L, Zheng X and Food Z: Protective effects of echinacoside, one of the phenylethanoid glycosides, on $\mathrm{H} 2 \mathrm{O} 2$-induced cytotoxicity in PC12 cells. neurodegenerative diseases 8: 9, 2009.

24. Wu C-R, Lin H-C and Su M-H: Reversal by aqueous extracts of Cistanche tubulosa from behavioral deficits in Alzheimer's disease-like rat model: relevance for amyloid deposition and central neurotransmitter function. BMC complementary and alternative medicine 14: 202, 2014.

25. Cai RL, Yang MH, Shi Y, Chen J, Li YC and Qi Y: Antifatigue activity of phenylethanoid-rich extract from Cistanche deserticola. Phytotherapy research 24: 313-315, 2010.

26. Gao Y, Zong C, Liu F, et al: Evaluation of the Intestinal Transport of a Phenylethanoid Glycoside-Rich Extract from Cistanche deserticola across the Caco-2 Cell Monolayer Model. PloS one 10: e0116490, 2015

27. Yoon J-H, Youn K, Ho C-T, Karwe MV, Jeong W-S and Jun M: p-Coumaric Acid and Ursolic Acid from Corni fructus Attenuated $\beta$-Amyloid 25-35-induced Toxicity through Regulation of the NF- $\kappa \mathrm{B}$ Signaling Pathway in PC12 cells. Journal of agricultural and food chemistry 62: 4911-4916, 2014

28. Zhu Y, Sun X, Gong T, He Q and Zhang Z: Antioxidant and Antiapoptotic Effects of 1,1'-(Biphenyl-4,4'-diyl)-bis (3- (dimethylamino)-propan-1-one) on protecting PC12 cells from $A \beta$-induced injury. Molecular pharmaceutics 11: 428-435, 2013.

29. Chen Y, Su Y, Run X, et al: Pretreatment of PC12 cells with $17 \beta$-estradiol prevents $A \beta$-induced down-regulation of CREB

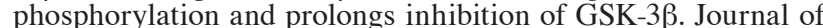
Molecular Neuroscience 50: 394-401, 2013.

30. Jiang B, Liu J, Bao Y and An L: Catalpol inhibits apoptosis in hydrogen peroxide-induced PC12 cells by preventing cytochrome c release and inactivating of caspase cascade. Toxicon 43: 53-59, 2004. 